\title{
Conceptualizing ethnicity, justice, and resistance during organizational change
}

\author{
by \\ AHMAD GLOVER \\ Touro University International \\ And \\ ERIC B. DENT, Ph. D. \\ University of North Carolina, Pembroke \\ P. O. Box 1510 \\ Pembroke, NC 28372 \\ 910-522-5789 (w), 910-521-6750 (x), Eric.Dent@uncp.edu
}

\begin{abstract}
This paper builds on work demonstrating that resistance to change is better conceptualized as resistance to loss and that change or loss has too many different manifestations to be addressed as a single phenomenon (Dent \& Goldberg, 1999a; 1999b). Consequently, we explore the loss of justice, perceived through the lens of ethnicity, as a factor in organizational change. Key variables are analyzed within three workplace constructs: change, ethnic culture, and justice, to explore the many dimensions of organizational resistance. It is argued that organizational citizenship behavior (OCB) serves as a useful proxy for resistance - reduced levels of OCB equate to increased resistance. The dimensions of American minorities are conceptualized and explored to challenge theories of workplace resistance. Lastly, to explore the complexity of organizational injustice, interpretations of non-instrumental procedural justice is viewed separately from distributive and interactional (anticipatory) justice. By addressing organizational injustice as one factor in reduced acceptance of change, the study opens the door for a new line of research into the many psychosocial factors that account for performance differences during the organizational change process.
\end{abstract}


Scholars are finding that technology, growth, globalization, and socioeconomic advance are connecting diverse American minority cultures in ways never before imagined (Adler, 1983; Alder \& Jelinek, 1986; Black \& Mendehall, 1990; Hall, 1960; Henderson \& Olasiji, 1994; Nevid \& Sta Maria, 1999; Sully de Luque \& Sommer, 2000; Taylor, Demont-Heinrich, Broadfoot, \& Jain, 2002). Moreover, American organizations have become increasingly engaged in operations employing heterogeneous social, ethnic, and gender cultures (Brockner \& Adsit, 1986; Chatman \& Jehn, 1994; Greenberg, 2001; Hall, 1960; Laurent, 1983; Sweeney \& McFarlin, 1997).Often these cultural groups are seen as reluctant to embrace organizational change initiatives (Cummings \& Worley, 1997). These conflicts between organizational change initiatives and employee cultures have been traditionally theorized as employee resistance to change (Miroshnik, 2002; Wilkins \& Dyer, 1988). Moreover, much of the research into cultural resistance has been associated with levels of individualism/collectivism, power/distance, uncertainty avoidance, or masculinity versus femininity (Hofstede, 1980; 1986). Contemporary research of diverse American cultures and resistance against change is spurring debate about the true meaning of resistance in Lewin's (1951) change management model.

Change, Resistance, Justice, and Ethnicity

Research is needed to examine the phenomenon of resistance and change by analyzing organizational resistance against injustice (Bies, 1987; Greenberg, 1987a; 1987b, 2001). Proper definition of workplace resistance is needed to help define the phenomena of change with respect to the broad and diverse minority cultures that make up the American melting pot. Part of the human experience is the need for support and 
acceptance at some level (Kegan, 1982; Lewin, 1951). At the basic level, humans are inherently creatures of habit with a need to assemble in like social groups (Lewin, 1935; 1939; 1940; 1943a; 1943b; 1943c; 1944; 1946; 1947; Schein, 1994; 1996; 2004). Within these groups, Americans seek equitable distribution systems to ensure mutual fairness (Adams, 1965). Some researchers have defined the very nature of maintaining human stability, equity, and habit as resistance to change (Celnar, 1999).

With American organizational resistance explored as a controllable variable, rather than a dynamic construct, some scholars have suggested that organizational resistance can be overcome via process (Cummings \&Worley, 1997). However, Dent and Goldberg (1999a) note that post-Lewin organizational resistance to change theories (Coch \& French, 1948) have blurred Lewin's conceptual meaning for social and organizational by addressing organizational resistance as a variable. Further, Dent and Goldberg argue that the variable defining organizational "resistance to change gets handed down" (27) without a clear understanding of Lewin's original social intent.

Organizational resistance has been defined across a broad spectrum as (a) allout rejection of change, (b) subversive behavior to counteract change, (c) limited disagreement with change processes, or (d) uncertainty towards change (Celnar, 1999). There has not been a model proposed to show the relationship between diverse American social groups and resistant behavior. Lewin's anthropological concept of resistance addresses conflicts between fields of psychological reality, which are preconditioned by social life spaces such as ethnicity. Dent and Goldberg (1999b), Piderit (2000) and others are beginning to posit resistance against loss of a tangible 
psychosocial factor as more representational of Lewin's original psychosocial meaning of resistance.

Researchers have suggested correlations between specific social factors and resistant employee behavior. American ethnicity is a key social consideration for all human behavior (Nevid \& Sta Maria, 1999). Likewise factors like ethnicity have a causal relationship with employee resistance during the change process (Lewin, 1951). Many of the tangible factors being proposed can be caused by social, national and ethnic cultures (Denison, 1996; Gaze, 2003; Greenburg, 2001; Miroshnik, 2002 within the frames of organizational climate, change, and justice (Bies, 1987; Greenberg, 1982; 1983; 1986; 1987a; 1987b; 2001; Moorman, 1991; Morrison, 1994; Wagner, 1995). American organizational and national culture has traditionally been defined and researched based on the values, norms, and roles of one organizational culture rather than exploring diverse employee perspectives (Williams, 1993). Even more, exploration of diverse American cultural norms and value differences has not been thoroughly dichotomized by ethnicity and gender (Hofstede, 1995; Spencer, 1986; Sweeney \& McFarlin, 1997). Medical, legal, marketing, and other non-organizational behavior based studies explore the complex dynamics of American minority cultures (Nevid \& Sta Maria, 1999). Likewise it is imperative that social and organizational resistance against change concepts be viewed based on these factors that could account for differing levels of resistance rather than simply applying the organizational resistance to change variable across the board (Piderit, 2000).

A better understanding of psychosocial resistance factors, in this case injustice, will increase organizational effectiveness when resistance against loss of a factor or 
changes to a known referent is fully understood (Wilkins \& Dyer, 1988). To understand social or organizational resistance, variables leading to the resistance construct should be better defined (Lewin, 1951). People resist the loss of a social or organizational structural known (Miroshnik, 2002), the loss of trust (Konovsky \& Pugh, 1994), or losses in a number of other variables in a social or organizational setting.

\section{Guiding Questions}

By following three literature streams (culture, justice, and change), we present a model to test resistance caused by loss in one factor, justice. Previous researchers of organizational justice concerning personality, culture, organizational resistance, and organizational citizenship behavior (OCB) have further investigated the relationships between justice and organizational change but have not shown an empirical relationship to organizational resistance during change (Celnar, 1999; Chawla, 1999; Folger \& Skarlicki, D. 1999; Harlan-Evans, 1994).

The questions that guide this conceptual exploration are:

1. How do preconditioned American ethnic social interpretations of justice relate to resistance during the organizational change process?

2. Do American organizations and members view change differently based on ethnicity?

3. Is resistance against loss of a tangible factor associated with the preconditioned ethnic understanding of justice during the organizational change process?

4. During the organizational change process, can meaningful resistance data be discerned from the measurement of employee extra role behavior based on 
well-established research into social differences and justice?

5. Is studying a single type of resistance, such as to injustice, a better approach to research than the classic resistance to change model?

Figure 1 graphically depicts the conceptual framework of this study.

Figure 1. Resistance as a Function of Change, Justice, and Culture (ethnicity)

Model for resistance to injustice.

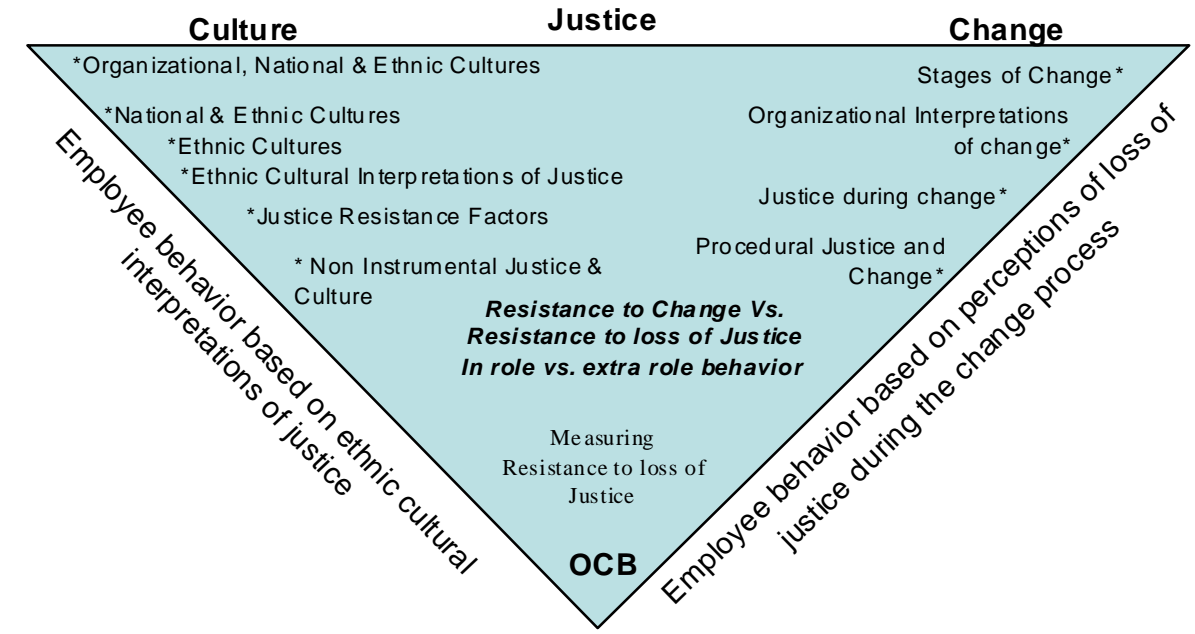

American ethnic and gender cultural interpretations of justice play a vital role in the change process. Likewise, during the change process the overall organization has a different conceptualization of change. Employee behaviors which challenge the de Ita between these viewpoints is traditionally theorized as resistance to change. The re are psychosocial factors that acco unt for "natural resistance" that takes place during the phenomenon of change. One such factor is justice. Based on culturally preconditions interpretations of justice (value, norms, etc..) me mbers will disp lay differing resistant-type extra role behaviors. These behaviors are manifest as low levels of non solicited OCB .

\section{Resistance Against Change}

Within American organizational change, groups attempting to implement change must explore the change phenomena from more than a temporal one-sided, or national, understanding of social change initiatives if organizational change is to become institutionalized (Nevid \& Sta Maria, 1999). Change is often introduced into organizational settings and immediately followed by failure (Pascale, Millemann, \& Gioja, 1997). Failure occurs when employee social perspectives and factors supporting those perspectives are not considered (Piderit, 2000). Often when nationalistic change management models or organizational change strategies are applied to American 
organizations, the likelihood of success is meager at best, if employee diversity is not thoroughly considered.

Many of these failures may be due to the lack of interoperable theory for the application of social change theory to the American workplace (Poole, 2004). The introduction of workplace change agents into American organizations has led organizations to view resistance as an employee-based problem (Coch \& French, 1848; Cummings \& Worley, 1997). In almost all cases, failed organizational change initiatives are blamed on the employee's resistance to change (Coch \& French, 1948; Cummings \& Worley, 1997). Resistance to change has been introduced as a variable without consideration for employee social interpretations of change. The organizational resistance to change concept has been inherently a one-sided assessment of change failure and this view is strictly a Theory X-based assumption of employee behaviors (e.g. McGregor, 1979). Change management, with respect to diverse employee cultures, appears to be one of the last American organizational development theories which still holds firm to McGregor's Theory X explanation of management and employee behavior.

Across the spectrum of change management research, resistance to change is defined as everything from obstinate employee behavior to employee failure to understand the need for change (Celnar, 1999). Researchers exploring the dynamic of organizational change have created models, concepts, and strategies to overcome and control these divisive employee behaviors even though the full structure and content of organizational resistance to change arguments are fundamentally ingrained in Theory $X$. The long-held belief that employees resist change and thereby cause organizational 
change initiatives to fail has been challenged (Celnar, 1999; Chawla, 1999).

Contemporary scholars studying organizational change management argue that these Theory X-based views of employee resistance to change are conceptually incorrect (Dent \& Goldberg, 1999a; 1999b, Piderit, 2000; Wilkins \& Dyer, 1988). Research should balance this argument by studying workplace resistance with respect to psychosocial Theory Y-based employee behaviors to support Lewin's and others' original research intents (Schein, 2000).

Rethinking Resistance to Change

By comparing American social and organizational factors that account for organizational resistance, resistance to change is better defined as resistance against the loss of something held dear during the change process (Dent \& Goldberg, 1999b; Piderit, 2000). As opposed to resistance to change, resistance against loss is not a condemnation of the overall change as presented in most resistance to change theory nor is it a resistance theory based solely on the employee's failure to embrace change. Resistance against poor management, resistance against stepping out of one's cultural comfort zone, resistance due to conflicting interpretation, and/or resistance against reduced fairness is considered under the resistance against change model. Modes of interpreting change can be further mediated by the differing American social groups' (as defined by US Census, 2000; and Henderson \& Olasiji, 1994) interpretations of reality (Lewin, 1951).

It has been argued that during change, employee perspectives of reality are the number one factor associated with resistance (Celnar, 1999; Cumming \& Worley, 1997; Dent \& Powley, 2002). Even further, the loss or reduction of expected outcomes has 
been directly linked to resistant behaviors (Dent \& Powley, 2002; Lewin, 1951).

Projected loss, conflict, management, challenge, or reduction of a specific psychosocial life space factor best defines Lewin's meaning of resistance. Resistance is not a unilateral employee disagreement with organizational change. Resistance occurs because of friction against employee paradigms (Hofstede, 1986; Lewin, 1935; Williams, 1993). This friction is often caused when the organization's nationalistic view of change is not congruent with the member's cultural interpretation of change, or conflicts in maximum prosperity and/or conflicts with life space boundaries. Evaluation of social and psychological resistance factors helps define those shifts, and moves organizational behaviorists away from viewing either the organization's interpretation of change or the member's cultural persecution separately (Nevid \& Sta Maria, 1999). Organizational, social, and employee perspectives of change should be viewed as coevolutionary (Lewin, Long, \& Carroll, 1999). More importantly, diagnosis of one organizational resistance factor, injustice, can lead to sound theory for dealing with other potential conflicts (Celnar, 1999; Chawla, 1999). Culture

Clearly one of the most well-studied organizational behavior constructs is culture (Greenberg, 1982; 1983; 1986; 1987a; 1987b; 2001; Hall, 1960; Hofstede, 1980; 1986; 1987; 1990; 1993; 1994; 2002; Lewin, 1935, 1939; 1940; 1943a; 1943b; 1943c; 1944; 1944; 1947; 1951; Schein, 1990; 1996; 2004; Williams, 1993). Scholars studying social and organizational behavior have noted that differing employee sub-cultures must be understood during the change process (Hofstede, 1995; Lewin, 1951; Schein, 1996). Lewin, Hofstede, and Schein note that part of the very nature of social or organizational 
change is restructuring cultural paradigms and norms. In essence, there are not two parallel processes for the management of employee background culture and organizational culture-change, but more precisely a covariant process occurs in unison. Misdiagnosis of conflicts between employee viewpoints and organizational perspectives of organizational change could heighten employee resistance (Triandis, 1990). Conflicts between organizational initiatives and member social cultures have been conceptualized as loss of a tangible relationship (Dent \& Goldberg, 1999a; 1999b; Greenberg, 2001). As noted by Schein, "Inattention to social systems in organizations has led researchers to underestimate the importance of [social] culture- shared norms, values, and assumptions- in how organizations function (1996, p. 41).

American organization culture theory has been created without defining the relationship between social influences on organizational culture (Connelley, 1994). Organizational behavior and development disciplines have been created on the assumption that American national culture is a single variable (Hofstede, 1986). Thereby, the complex makeup of differing American ethnic and gender cultures has been likened to other ethnic specific nations such as Spain, Italy, Japan, and Nigeria. In viewing American national culture as a single variable, American social and organizational cultural correlations have been ignored. The time has come to address and explore the relationship between diverse American cultures and organizational culture.

There are a number of social group (life space) sub-cultures operating within American organizations (gender, ethnicity, national, societal), which are critical to organizational success (Greenberg, 2001; Loomis, 1983; Williams, 1993). Scholars find 
it virtually impossible to address American organizational development or behavior without reference to social culture (Schein, 1996; Wilkins, 1987; Wilkins \& Dyer, 1988). Likewise, organizational climates engendered in differing social cultures have become a key component of organizational change research (Denison, 1996). However, American organizational climate and culture research has centered around one defining variable without a concept to define the relationship between diverse American ethnic groups. Key components addressed in climate research, well-known inter-personal cultural dimensions, and organizational change perspectives should not be viewed as separate concepts for the diagnosis of employee organizational behavior. Using well-established research into national cultural differences and the diverse social groups that define the American social culture, research has matured to a point where researchers can explore the relationship between the organizational ideas of change and member perspective (psychosocial preconditioning) together (Census, 2000; Henderson \& Olasiji, 1994; Hofstede, 1980; 1986; 1987; Lewin et al., 1999). By studying member and organizational understanding of organization change together, research is beginning to address whether social preconditioning has a direct correlation to perceptions of injustice. Understanding this relationship may reduce worker disagreement with organizational change initiatives. The main issue for contemporary American change management researchers is how to address differing social perceptions, with respect to fairness, across multiple organizational behavior disciplines, while interpreting the organization and employee understanding of the same change processes (Laurent, 1983). 
Cultural Interpretations of Change

Although Hofstede (1986) and Schein (1996) were among the first post-Lewin researchers to explore the importance of cultural perspectives within organizations, Van de Ven and Poole (1995) were the first to model differing conceptualizations of change based on social and national perspectives. They theorized that four social typologies define national perspectives of change (life cycle, teleology, evolution, and dialectic). Van de Ven and Poole did not correlate the social perspective of change with membership in an ethnic culture, gender, or social group (Poole, 2004). This type of coevolutionary research (Lewin et al., 1999) is critical in establishing the bridge between organizational and member perspectives of reality and fairness. The organization takes its values, norms, and perspectives from the viewpoint of each member's preconditioned culture (Hofstede, 1986; Markus \& Kitayama, 1991; Spencer, 1986; Traindis, 1989; Wagner, 1995). The organization is not a stand-alone organism that has no association with its members (McKelvey, 1999). As noted by Wilkins and Dyer (1988), "Organizational culture is socially acquired and shared knowledge that is embodied in specific and general organizational frames of reference" (p. 523). Organizational researchers should not discount the importance of differing American minority points of view because the employee's socially acquired perspective of reality helps define the organization.

When an organization attempts to use one perspective to initiate change, differing minority members viewpoints of justice are often overlooked (Ely, 1995; Farh et al., 1997; Hofstede, 1993; Spencer, 1986). The conflict between different American minority viewpoints, based on "our way is the best way" (Miroshnik, 2002 p. 537) has 
led to segregated views of organizational justice and mistrust for organizational initiatives. Employees are likewise beginning to discredit researchers studying organizational behavior if all cultures within the organization are not considered (Nevid \& Sta Maria, 1999; Lind \& Tyler, 1988, Tyler, 1994). In most instances, change initiatives are met by out-group minority interpretations that the organization is obtuse about member needs (Goldstein, 1989; Harlan-Evans, 1994; Kyle, 1993; Miroshnik, 2002; Tyler, 1994). These conflicts in viewpoint have in some instances led to increased resistance and distrust when boundaries were not defined and/or explored (Folger \& Skarlicki, 1999; Shapiro \& Kirkman, 1999).

An Increased Emphasis on Diversity Research

Much of American management and natural cultural research used in social science has been transferred from European social studies (Hofstede, 1986; Lommis, 1983; Mead, 1945; Triandis, 1990). A singular American national culture has been defined and accepted within organizational behavior research even though the national culture of America is more diverse than any other nation in the world (Henderson \& Olasiji, 1994; Triandis, 1990). Some American researchers have questioned the logic of measuring American national culture or organizational culture as a unified variable due to America's unique and diverse makeup (Farh et al., 1997; Gaze, 2003; Jasso, Massey, Rosenzweig, \& Smith, 2004; Loomis, 1983; Mead, 1904; 1946; NORC, 2004; Triandis, 1990; Wilkins \& Dyer, 1988). American ethnic sub-cultural factors are not typically used in studies of American organizational change. Social science research has sought to define American national culture as the behaviors of the majority of Americans rather than defined by the variety of employee members (Hofstede, 1986). 
As implied by early American researchers, America is far too complex to study as a single national culture (Lewin, 1951).

Henderson and Olasiji (1994) and Loomis (1983) propose that the American melting pot is made up of over nine ethnic groups (Native American; British/Irish; Western, Central, and Northern European; Southern European; Eastern European Slavs; Eastern European non-Slavs; Asians; The Americas; and, Africans and African Americans), each of which comprises a number of race-specific demographics with separately defined social roots. Five of these ethnic groups are categorized by the U.S .Census (2000) and most social science researchers as white, even though researchers offer realistic homeland cultural differences for each of the aforementioned ethnicities (Hofstede, 1980; Laurent, 1983; Loomis, 1983; Triandis, 1989). The assertion that one culture permeates the American national culture is being challenged by prominent social science researchers (National Organization for Research at the University of Chicago, NORC, 2004 and the New Immigrant Survey from Jasso, Massey, Rosenzweig, \& Smith, 2004).

Ethnic Minority

Postmodern immigration and minority participation in the American workplace has led some researchers to explore the relationship between minority and majority cultural relationships (Earley \& Mosakowski, 2004; Farh et al., 1997; Henderson \& Olasiji, 1994; Hofstede, 1980; 1986; 1987; 1990; 1993; 1994; 2002; Jasso, Massey, Rosenzweig, \& Smith, 2004; Kolman, Noorderhaven, Hofstede \& Dienes, 2003; NORC, 2004). Moreover, Hofstede (1980; 1983) has studied many national cultures (homeland) that are ethnically represented in America and found drastic differences in 
interpretations of reality (fairness) and reactions to organizational issues such as change.

These ethnic perspectives are often overlooked in the concept of American national assimilation (Nevid \& Sta Maria, 1999; NORC, 2004; Laurent, 1983). Scholars have noted that social and ethnic composition define both national and organizational cultures (Earley \& Mosakowski, 2004; Hofstede, 1980; 1987; 2002; Kolman et al., 2003, Loomis, 1983; Schein, 1996, 2000). The parochial view of organizational culture supports the misguided belief of one American cultural view (Black \& Mendenhall, 1990; Greenberg, 2001; Hofstede, 1993; Miroshnik, 2002). Miroshnik, Black, and Mendenhall suggest that this view can be extremely harmful to social or organizational change and human cultural relations (Farh et al., 1997; Hofstede, 1980; 1993; 2003). Previous research has studied resistance as a single variable paired with one American national culture variable. Parochial cultural perspectives have often been the only concept available to define American organizational change. Consequently, the following propositions are offered:

Proposition 1: Definitions of resistance differ based on ethnicity.

Proposition 2: Interpretations of change vary based on ethnicity. Justice

In order to address organizational behavior and responses to injustice, social norms affecting organizational behavior must be explored first (Schein, 2000). Age, sex, ethnicity, gender, experience and other social life spaces contribute to the way realities are conceptualized (Hofstede, 1980; Kegan, 1982; Pate, 1987) and changes are interpreted (Figure 2). Processes which are in line with inter-personal interpretations of 
fairness and reality boundaries are usually well-received (Wilkins \& Dryer, 1988).

Interpretations of just changes often generate higher levels of organizational extra role OCB (Chawla, 1999). Organizational change processes going against social interpretations of the need for change, boundaries, and/or perceptions of fairness are often fraught with conflict and lower levels of OCB (Farh et al., 1997; Tyler, 1994).

Figure 2. Block Diagram of Resistance, Justice, Culture, OCB Relationship

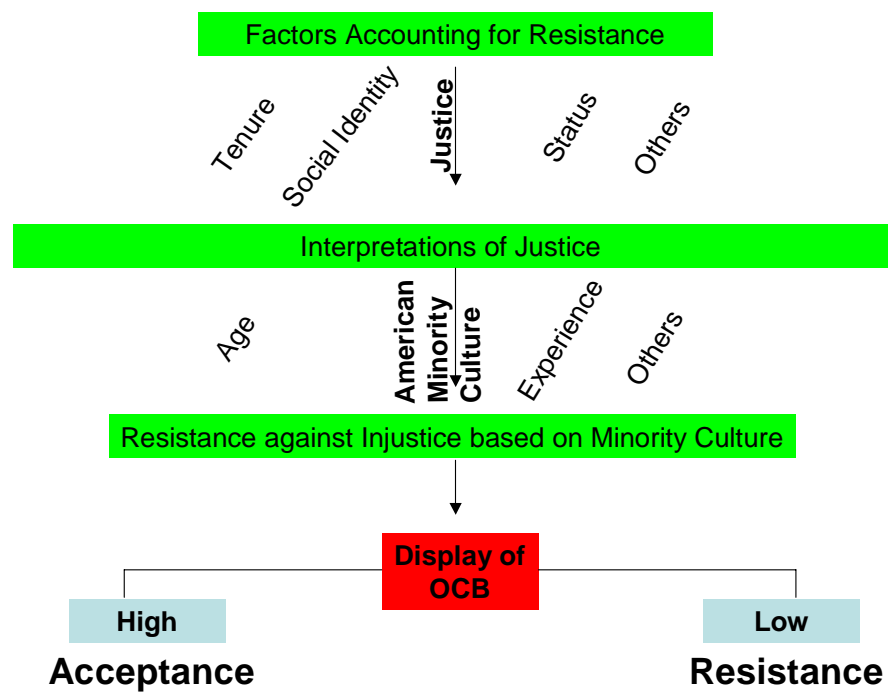

Correlations discovered between justice and other organizational behaviors and development fields have been inherently one-sided without consideration for psychosocial resistant factors. Greenberg (2001) notes that the best hope of establishing a unified organizational justice theory is to conceptualize justice in relationship to culture and other well-founded organizational behavior disciplines. Likewise, procedural justice has been deemed the most favorable dimension of justice by which to study reactive process and content in relationship to organizational behavior, because perceptions of distributive and interactional justice are based on 
employees' understanding of procedural justice (Greenberg, 2001) The study of cultureprocedural justice supports the contention that interpretations of rules directing fairness are an essential part of change (Lewin, 1935; 1936; 1951).

Distributive (fair playing field), and interactional/anticipatory (fair dealings) justice each has a direct relationship with levels of commitment, acceptance, and job satisfaction (Brockner \& Adsit, 1986; Folger \& Konovsky; 1989; Lind \& Tyler, 1988; Moorman, 1991). These personal translations of distributive and interactional justice affect agreement to resistance against organizational decisions (Farh, et al., 1997; Folger \& Skarlicki, 1999; Mackenzie, Podsakoff, \& Ahearne, 1998; Smith \& Tyler, 1996; Tyler, 1994). Most importantly both distributive and interactional justice are based on how procedural justice (fair rules) is defined in the workplace (Greenberg, 2001). Likewise, perceptions of the need for distributive and interactional justice have been found to differ (Thibaut \& Walker, 1975; 1978). Differences in conceptualization of distributive and interactional justice are based on national and gender culture (Brockner \&Adsit, 1986; Farh, et al., 1997; Folger \& Skarlicki, 1999; Smith \& Tyler, 1996; Tyler, 1994). However, employee interpretations of procedural justice have not differed by gender (Celnar, 1999; Chawla, 1999). This analysis leads to the following proposition:

Proposition 3: Perceptions of non-instrumental injustice differ based on ethnicity. Resistance Against Injustice: New Line of Research

Farh et al. (1997), Folger and Skarlicki (1999), and Shapiro and Kirkman (1999) are beginning to explore an exciting new relationship among justice-culture-resistance and have found a relationship between organizational resistance (in the traditional sense), organizational justice, national culture, and OCB (from a non-theoretical justice 
perspective). In all cases, organizational justice, and specifically procedural justice, has been found to have a strong correlation with OCB (Greenberg, 2001; Lind \&Tyler, 1988; Mackenzie et al., 1998; Tyler \& Bies, 1990). However, all studies thus far have been based on organizational justice and no known studies have attempted to address Greenberg's concerns of exploring organizational justice with respect to other established psychosocial theories such as resistance against change.

As noted earlier, organizational supportive behaviors during the change process are best termed supra or extra role behaviors (Bateman \& Organ, 1983; Organ, 1988). Extra role behaviors are "behaviors that cannot be proscribed or required in advance for a given job" (p. 588). Bateman and Organ (1983) posit that, "It is likely that more satisfied persons display more of the prosocial, citizen behaviors" (p. 588) and conversely dissatisfied employees will display lower levels of OCB, or resistance. Extra role behaviors within the OCB variable provide the best analysis of organizational resistance because "citizen behaviors... represent actions more under the volitional control of the worker than conventional productivity measures" (p. 592). Extra role behaviors are indicators of psychosocial interpretations of injustice (Celnar, 1999; Farh et al., 1997; Folger \& Skarlicki, 1999; Shapiro \& Kirkman, 1999) insomuch as lower levels of extra role behavior have been associated with rejection of organizational change (Celnar, 1999; Mabin, Forgeson, \& Green, 2001; Piderit, 2000). In a study of Chinese ethnicities and gender cultures, Farh et al. (1997) validated the relationship between levels of OCB and preconditioned ethnic cultural interpretations of procedural justice. Farh et al. found that lower levels of OCB (40 percent) might be based on ethnicity. Much like the Farh et al. study, Celnar, Folger and Skarlicki, and Shapiro and 
Kirkman found that lower levels of OCB translate into organizational resistant behaviors among Americans based on member perceptions of justice. However, none of these studies took into account the diversity of ethnic culture within the United States, which cannot be singularly defined (Nevid \& Sta Maria, 1999; NORC, 2004).

The OCB variable measures normal, abnormal, and differing levels of employee support related to member satisfaction or resistance against social life space boundary shifts (Organ, 1983; Turnipseed, 1996). More importantly, the OCB model has been used previously to operationalize resistance to change theory, universal procedural justice, personality, and ethnicity with respect to satisfaction or turnover in other organizational studies (Celnar, 1999; Farh et al., 1997; Folger \& Skarlicki, 1999; Mackenzie et al., 1998; Moorman et al., 1998; Shapiro \& Kirkman, 1999). Justice-based scholars note that human behaviors have been found to differ based on perceptions that the organization wants to do the right thing (Morrison, 1994; Spencer, 1986; Tyler, 1994). An organization's effort to make rules to ensure that it does the right thing (procedural justice) has been conceptualized as dimensions of procedural justice: instrumental and non-instrumental (Lind \& Tyler, 1988; Tyler, 1988).

Specific to procedural justice-OCB, research suggests that employees display higher levels of OCB in organizations that have the perception of natural fairness (noninstrumental justice) than in organizations that have instruments in place that mandate fairness to control employee behavior (Greenberg, 1983; 1986; 1987a; 1987b; 2001; Lind \& Tyler, 1988; Moorman et al., 1998; Robbins, Summers, Miller, \& Hendrix, 2000). The acuity of fairness is due in part to the employee's perception that the organization that is not forced into supporting ethnic and gender cultural perceptions of justice is 
seen as fairer (Farh et al., 1997; Folger \& Sharlicki, 1999). Basically, an organization that does the right thing just because it is the right thing (non-instrumental justice) and not because a documented rule (instrumental justice) requires the organization to be fair to all cultures is supported more by all employees than organizations that are forced to respect the fairness of all members (Greenberg, 2001; Farh et al., 1997; Tyler, 1988; Van Dyne \& LePine, 1998). It can therefore be said that perceptions of non-instrumental procedural justice should have a direct relationship with levels OCB during the change process when documented procedures do not mandate just behavior (Lind \& Tyler, 1988).

OCB based on non-instrumental procedural justice provides the strongest indicators of organizational resistance (a) because Chinese ethnic extra role behaviors have been empirically tested within the OCB-justice variables in relationship to national culture (Farh et al., 1997); (b) socially preconditioned behaviors are uncontrolled and unsolicited by the employer (Organ, 1988), and (c) previous research has validated a correlation between organizational resistance, social groups, or ethnic culture (Lewin, 1951), procedural justice, and OCB (Folger \& Skarlicki, 1999; Shapiro \& Kirkman, 1999). These lower levels of OCB have been viewed as an indicator of levels of organizational resistance within traditional organizational resistance-to-change models (Chawla, 1999; Folger \& Skarlicki, 1999; Mackenzie et al., 1998; Shapiro \& Kirkman, 1999). OCB should present a similar relationship with gender/ ethnicity-resitanceinjustice within the Dent and Goldberg theory (1999a; 1999b). Preconditioned Resistance Against Injustice Folger and Skarlicki (1999) support and validate the argument that organizational 
justice, resistance against organizational change, and social culture are correlated with employee-organizational congruence. They posit that justice should be explored in concert with other factors such as resistance and culture due to interaction amongst dimensions of justice. Their findings suggest a strong correlation between socialorganizational justice and organizational resistance. As has been noted, this correlation may be due to American ethnic diversity, social preconditioning, and gender, which they do not explore.

Supporting the Folger and Skarlicki findings, Shapiro and Kirkman (1999) propose measurement of employee behaviors during organizational change to determine interpretations of organizational justice. The scales they put forward conceptualize the measurement of American organizational justice and American organizational resistance (OCB), mediated by diverse American ethnic and gender cultures. Shapiro and Kirkman's propositions are supported by Chawla (1999) and Celnar's (1999) findings that there is a correlation between organizational change, psyche, personality, national culture, organizational justice, and resistance. Perceptions of procedural justice do correlate with resistance, supporting indications by other researchers that lower levels of OCB can be resistant against injustice (Celnar, 1999; Tyler, 1994). These findings lead to the following propositions:

Proposition 4: Lower levels of perceived non-instrumental justice will mean decreased levels of OCB (translated as resistance to injustice).

Proposition 5: In organizations with lower levels of OCB, levels of resistance differ based on ethnicity. 
Implications and Opportunities for Theoretical Extension

Researchers are beginning to hone in on the idea of studying OCB, personality, cultural justice, and/or change (resistance) together (Celnar, 1999; Folger \& Skarlicki, 1999; Moorman, 1991; Morrison, 1994; Van Dyne et al., 1994). This view provides the starting point to address employee Theory Y-based resistant behaviors. Most researchers in this area have viewed organizational resistance to change in the traditional sense by using resistance as a dependant variable that can be overcome or managed away, separate and apart from employee social interpretations of reality, with the exception of Dent and Goldberg (1999a, 1999b), Dent and Powley, (2002), and Piderit, (2000).

This research does not suggest that every employee's social interpretation be considered during all organizational initiatives (Hofstede, 2002; Horton, 2000). This field of research suggests that the parochial and ethnocentric rules do not have a place in today's ethnically and gender diverse American organizations. The same warnings of social consideration in organizational research noted by Lewin in the 1930s and 1940s are prevalent in organizational studies today and the time is long overdue for psychosocial researchers to address this issue of human dignity. Every employee's preconditioned perceptions of fairness must be considered if organizations are to have any hope of achieving higher levels of successful change (Laurent, 1983; Lee \& Farh, 1999; Loomis, 1983). A return to Theory Y-based organizational behavior research is needed to address organizational resistance with respect to empathy. References

Adams, J. (1965). Inequity in social exchange. In Berkowitz, L. (Ed). Advances in 
experimental social psychology, 2(1), p. 267-299. New York: Academic Press.

Alder, N. (1983). Cross-Cultural Management Research: The Ostrich and the Trend. Academy of Management Review, 8, p. 226-232.

Alder, N. \& Jelinek M. (1986). "Is ‘Organization Culture' Culture bound?” Human Resource Management, 25, p. 73-90.

Bateman, T. \& Organ, D. (1983). Job satisfaction and the good soldier; the relationship between affect and employee citizenship. Academy of Management Journal 26, p. 587-596.

Black, J. \& Mendenhall, M. (1990). Cross-cultural training effectiveness: A review and a theoretical framework for future research. Academy of Management Review,15(1), p. 113- 136.

Bies, R. (1987). "The predicament of injustice: The management of moral outrage." In Cummings L. \& Staw B. (eds), Research in Organizational Behavior, 9: p. 289319.

Brockner, J. \& Adsit, L. (1986). The moderating impact of sex on the equity satisfaction relationship: A field study. Journal of Applied Psychology, 71, p. 585-590.

Celnar, C. (1999). Personality and Justice Predictors of Workplace Resistance to Organizational Change, University of Calvary, Master of Science: Thesis.

Chatman, J. A., \& Jehn, K. A. (1994). Assessing the relationship between industry characteristics and organizational culture: How different can you be? Academy of Management Journal, 37(3), p. 522-554.

Chawla, A. (1999). Organizational Change Initiatives as Predictors of Resistance to 
Change. The University of Guelph. Masters of Arts: Thesis.

Coch, L. \& French, J. R. P. (1948). Overcoming resistance to change. Human relations, 1(4), p. $512-532$

Cummings, T. G. \& Worley C.G. (1997). Organization Development and Change (6 $6^{\text {th }}$ Edition). South-Western College Publishing

Denison, D. R. (1996). What is the difference between organizational culture and organizational climate? A native's point of view on a decade of paradigm wars. Academy of Management Review, 21(3), p. 619-655.

Dent, E., \& Goldberg, S. (1999a). Challenging "Resistance to Change". The Journal of Applied Behavioral Science, 35(1), p. 25-42.

Dent, E. \& Goldberg, S. (1999b). Resistance to Change: "A limiting perspective". The Journal of Applied Behavioral Science, 35(1), p. 45-47.

Dent E. \& Powley, E. (2002). Employees Actually Embrace Change: The Chimera of Resistance. Journal of Applied Management and Entrepreneurship, 7(2), p. 5663

Earley, P. C. \& Mosakowski, E. (2004). Cultural Intelligence. Harvard Business Review, 10(1), p. 1-9.

Ely, R. J. (1995). The power in demography: Women's social constructions of gender identity at work. Academy of Management Journal, 38, p. 589-634. 
Farh, J., Earley, P.C., \& Lin, S. (1997). Impetus for action: A cultural analysis of justice on reactions to pay raise decisions. Administrative Science Quarterly, 42, 3, p. 421-444.

Folger, R. \& Konovsky, M. (1989). Effects of procedural and distributive justice on reactions to pay raise decisions. Academy of Management Journal, 32, p. 115130.

Folger, R. \& Skarlicki, D. (1999). Unfairness and resistance to change: hardship as mistreatment. Journal of Organizational Change Management. 12(1), p. 31-41.

Gaze J. (2003). Reception for Diversity In an Overseas U.S. Navy Medical Treatment Facility Touro University International. College of Business Administration Dissertation. Retrieved on 19 January 2004 from: http://graduate.tourou.edu/phd/dissprop/proposals/approved\%20proposals.htm.

Greenberg, J. (1982). Approaching equity and avoiding inequity in groups and organizations. In Greenberg, J. \& Cohen, R. (Eds). Equity and justice in social behavior (p. 389-435). New York: Academic Press.

Greenberg, J. (1983). Overcoming egocentric bias in perceived fairness through selfawareness. Social Psychology Quarterly, 46(1), p. 152-156.

Greenberg, J. (1986). Differential intolerance for inequity from organizational and individual agents. Journal of Applied Social Psychology, 16(1), p. 191-196.

Greenberg, J. (1987a). Reactions to procedural injustice in payment distribution: Do the means justify the ends? Journal of Applied Psychology, 72(1), p. 55-61. 
Greenberg, J. (1987b). A Taxonomy of organizational justice theories. The Academy of Management Review, 12(1), p. 9-22.

Greenberg, J. (2001). Studying organizational justice cross-culturally: Fundamental challenges. International Journal of Conflict Management, 12(4), p. 365-376.

Goldstein, J. (1989). The affirmative core of resistance to change. Organizational Development Journal (1)1, p. 32-38.

Hall, E. (1960). The silent language in international business. Harvard Business Review.

Harlen-Evans, T. (1994). The resistance factor. Directors and Boards (19)2, p. 31-32.

Henderson G. \& Olasiji, D. (1994). Migrants, Immigrants, and Slaves; Racial and Ethnic Groups in America. University Press of America, Lanham, MD: London, England

Hofstede, G. (1980). Culture's Consequences. International Differences in Work Related Values, Beverly Hills, CA: Sage.

Hofstede, G. (1986). The Cultural relativity of Organizational Practices and Theories. Journal of International Business Studies. 14 (2), p. 75-89.

Hofstede, G. (1987). The Applicability of McGregor's Theories in South East Asia. The Journal of Management Development (6)3, p. 9-19.

Hofstede, G. (1990). Measuring Organizational Cultures: A Qualitative and Quantitative Study Across Twenty Cases. Administrative Science Quarterly (35)2, p. 286-307.

Hofstede, G. (1993). Cultural constraints in management theories. Academy of Management Executive (7)1, p. 81-94. 
Hofstede, G. (1994). Management scientists are human. Management Science (40)1, p. 4-14.

Hofstede, G. (2002). Dimensions do not exist; A reply to Brendan McSweeney. Human Relations, 55,11, p. 1355.

Horton, R. (2000). Globalization's cultural consequences. The annals of the American Academy, 7, p. 140-151.

Jasso, G, Massey, D. S., Rosenzweig, M. R., \& Smith, J.P. (2004). New Immigrant Survey. Princeton University. Retrieved on 10 November 2004 from: http://nis.princeton.edu/

Kegan, R. (1982). The evolving self: Problem and process in human development. Cambridge, MA: Harvard University Press.

Kolman, L., Noorderhaven N., Hofstede, G., \& Dienes, E. (2003). Cross-cultural differences in Central Europe. Journal of Managerial Psychology (18), 1/2, p. 7689.

Konovsky, M. \& Pugh, S. (1994) Citizenship behavior and social exchange. Academy of Management Journal (1)37, p. 656-669

Kyle, N. (1993). Staying with the flow of change. Journal for Quality and Participation (16)4, p. 34-42.

Laurent, A. (1983). The cultural diversity of western management conceptions. International Studies of Management and Organizations, 8, p. 75-96. 
Lee, C. \& Farh, J. (1999). The effects of gender in organizational justice perception. Journal of Organizational Behavior, 20(1), p. 133-144.

Lewin, K. (1935). Psycho-Sociological Problems of a Minority Group. Character and Personality, 3, p. 175-187. In American Psychological Association. (2000). Resolving Social Conflicts \& Field Theory in Social Science. Washington: DC.

Lewin, K. (1936). Some social-psychological differences between the United Sates and Germany. Character and Personality 4, p. 265-293. In American Psychological Association. (2000). Resolving Social Conflicts \& Field Theory in Social Science. Washington: DC.

Lewin, K. (1939). Experiments in Social Space. Harvard Educational Review, 9, p. 2132. In American Psychological Association. (2000). Resolving Social Conflicts \& Field Theory in Social Science. Washington: DC.

Lewin, K. (1940). Formalization and progress in psychology. University of lowa Studies in Child Welfare, 16(3), p. 9-42. In American Psychological Association. (2000). Resolving Social Conflicts \& Field Theory in Social Science. Washington: DC.

Lewin, K. (1943a). Cultural Reconstruction. Journal of Abnormal and Social Psychology, 38, p. 166-173. In American Psychological Association. (2000). Resolving Social Conflicts \& Field Theory in Social Science. Washington: DC.

Lewin, K. (1943b). Defining the field at a given time. Psychologist Review, 50, p 292310. In American Psychological Association. (2000). Resolving Social Conflicts \& Field Theory in Social Science. Washington: DC. 
Lewin, K. (1943c). Psychology and the process of group living. Journal of Social Psychologist, 17, p 113-131. In American Psychological Association. (2000). Resolving Social Conflicts \& Field Theory in Social Science. Washington: DC

Lewin, K. (1944). Constructs in psychology and psychological ecology. University of lowa Studies in Child Welfare, 20, p. 1-29. In American Psychological Association. (2000). Resolving Social Conflicts \& Field Theory in Social Science. Washington: DC.

Lewin, K. (1946). Action research and minority problems. Journal of Social Issues, 2 p. 34-46. In American Psychological Association. (2000). Resolving Social Conflicts \& Field Theory in Social Science. Washington: DC.

Lewin, K. (1947). Frontiers in-group dynamics. Human Relations, 1, p 2-38. In American Psychological Association. (2000). Resolving Social Conflicts \& Field Theory in Social Science. Washington: DC.

Lewin K. (1951). Field Theory in Social Science: Selected papers. (D. Cartwright Ed) New York Harper.

Lewin, A., Long, C., \& Carroll, T. (1999). The coevolution of new organizational forms, Organizational Science, 10(5), p. 535-550.

Lind, E. \& Tyler, T. (1988). The social psychology of procedural justice. New York: Plenum.

Loomis, O. (1983). Cultural conservation: The protection of cultural heritage of the United States. Washington: Library of Congress. 
Mabin, V., Forgeson, S., \& Green, L. (2001). Harnessing Resistance: Using the Theory of Constraints to Assist Change Management. Journal of European Industrial Training. 25(2/3/4), p. 168.

Mackenzie, S. B., Podsakoff, P. M., \& Ahearne, M. (1998). Some possible antecedents and consequences of in-role and extra-role salesperson performance. Journal of Marketing, 62(3), p. 87-98.

Markus, H. \& Kitayama, S. (1991). Culture and the self: Implications for cognition, emotion, and motivation. Psychological Review, 98, p. 224-253.

McGregor, D. (1979). An Uneasy Look at Performance Appraisal. In T. H. Panen (Ed)., Classics of Personnel Management, Oak Park, IL: Moore Publishing, pp. 353359.

McKelvey, B. (1997). Quasi-National Organizational Science. Organizational Science, 8(4), p. 352-380.

Miroshnik, V. (2002). Culture and International Management: A Review. The Journal of Management Development. 21(7/8), p. 521-545.

Morrison, E. (1994). Role definitions and organizational citizenship behavior: The importance of employee's perspective. Academy of Management Journal, 637, p. $1543-1567$.

Moorman, R. (1991). Relationship between organizational justice and organizational citizenship behavior: Do fairness perceptions influence employee citizenship? Journal of Applied Psychology, 6, p. 845-855.

Moorman, R., Blakely, G., \& Niehoff, B. (1998). Does perceived organizational support mediate the relationship between procedural justice and organizational 
citizenship behavior? American Management Journal, 41, p.3 51-357.

Nevid, J. \& Sta Maria, N. L. (1999). Multicultural issues in qualitative research. Psychology \& Marketing, 16(4), p. 305-326.

NORC (2004). New Immigrant Survey: National Organization of Research at the University of Chicago. Retrieved on 29 October 2004 from: http://www.norc.uchicago.edu/issues/ecopop8.asp

Organ, D. (1988) Organizational Citizenship Behavior: The Good Soldier Syndrome, Lexington Books, Lexington, MA.

Pascale, R., Millemann, M., \& Gioja, L. (1997). "Changing the way we change," Harvard Business Review, 75(6):127-139.

Pate, L. (1987). Understanding Human Needs. Management Decision (25)6, p. 58-65

Piderit S. (2000). Rethinking Resistance and Recognizing Ambivalence: A Multidimensional View of Attitudes Towards and Organizational Change. Academy of Management Review. 25(4), p. 783-795.

Poole, S. (2004). Interview with author on 13 December 2004. Telephone conference Washington D.C \& College Station, Texas. Real Player recording in possession of author.

Robbins, T. L., Summers, T. P., Miller, J. L., \& Hendrix, W. H. (2000). Using the groupvalue model to explain the role of non-instrumental justice in distinguishing the effects of distributive and procedural justice. Journal of Occupational and Organizational Psychology, 73(4), p. 511-518. 
Schein, E. (1990). Organizational Culture. American Psychologist, 45(2), p. 109-119.

Schein, E. (1996). Culture: The Missing Concept in Organization Studies. Administrative Science Quarterly. 41(2), p. 229-241.

Schein, E. (2000). Kurt Lewin's Change Theory in the filed and in the classroom: Notes toward a model of managed learning. Retrieved on October 10, 2004 from: http://www.a2zpsychology.com/articles/kurt_lewin's_change_theory.htm

Shapiro, D. \& Kirkman, B. (1999). Employees' reaction to the change to work teams: The influence of "anticipatory" injustice. Journal of Organizational Change Management, 12(1), p. 51-60.

Smith, H.J., \& Tyler, T.R. (1996). Justice and power: Can justice motivations and superordinate categorizations encourage the advantaged to support policies, which redistribute economic resources and encourage the disadvantaged to willingly obey the law? European Journal of Social Psychology, 26, p. 171-200.

Spencer, D. (1986). Employee voice and employee retention. Academy of Management Journal, 29, p. 488-502.

Sully de Luque, M.F., \& Sommer, S.M. (2000). The impact of culture on feedbackseeking behavior: An integrated model and propositions. Academy of Management Review, 25, p. 829-849.

Sweeney, P. \& McFarlin, D. (1997). Process and outcome: Gender differences in the assessment of justice. Journal of Organizational Behavior, 18(1), p. 83-98.

Taylor, B., Demont-Heinrich, C., Broadfoot, K., Dodge, J., \& Jain, G. (2002). New Media and the Circuit of Cyber-Culture; Conceptualizing Napster. Journal of Broadcasting and Electronic Media. 46(4), p. 607-630. 
Thibaut, J. \& Walker, L. (1975). Procedural justice: A psychological analysis. Hillsdale, New Jersey: Erilbaum.

Thibaut, J. \& Walker, L. (1978). A theory of procedure. California Law Review, 66(1), p. 541-566.

Triandis, H. (1989). The self and social behavior in differing cultural contexts. Psychological Review, 96(3), p. 506-520.

Turnipseed, D. (1996). Organizational citizenship behavior: an examination of the influence of the workplace. Leadership and Organization Development Journal. 17(2), p. $42-48$.

Tyler, T. (1994). Psychological models of the justice motive. Journal of Personality and Social Psychology, 67, p. 850-863.

Tyler, T. \& Bies, R. (1990). "Beyond formal procedures: The interpersonal context of procedural justice." In Carroll, J. (ed.). Applied Social Psychology in Business Settings: p. 77-98. Hillsdale, NJ.

US Census. (2000, December). Retrieved September 21, 2004 from http://factfinder.census.gov/servlet/QTTable?_bm=y\&-geo_id=01000US\&qr_name=DEC_2000_SF1_U_DP1\&-ds_name=DEC_2000_SF1_U

Williams, R. (1993). Culture is ordinary. In Gray, A. \& Mcguigan, J. (Eds), Studying culture: An introductory reader. P. 5-14. London: Edward Arnold.

Wilkins, A. L., \& Bristow, N. J. (1987). For successful organization culture, honor your past. Academy of Management Executive, 1(3), p. 221-228.

Wilkins, A., \& Dyer, G. (1988). Toward Culturally Sensitive Theories of Culture Change. Academy of Management. 13(4), p.522-534. 
Van de Ven, A. H., \& Poole, M. S. (1995). Explaining Developmental and Change in Organizations. Academy of Management Review 20(3), p. 510-513.

Van Dyne, L., Graham, J. \& Dienesch, R. (1994). Organizational Citizenship behavior: Construct redefinition, measurement, and validation. Academy of Management Journal, 37, p. 765-802.

Van Dyne, L., \& LePine, J. A. (1998). Helping and voice extra-role behavior: Evidence of construct and predictive validity. AMJ, 41, p. 108-1 